\title{
Review
}

\section{Smith-Magenis Syndrome-Clinical Review, Biological Background and Related Disorders}

\author{
Berardo Rinaldi $^{1}(\mathbb{D})$, Roberta Villa ${ }^{1}$, Alessandra Sironi ${ }^{2,3}{ }^{(D}$, Livia Garavelli ${ }^{4}$, Palma Finelli ${ }^{2,3,+}$ \\ and Maria Francesca Bedeschi $1, *,+\mathbb{D}$
}

Citation: Rinaldi, B.; Villa, R.; Sironi, A.; Garavelli, L.; Finelli, P.; Bedeschi, M.F. Smith-Magenis

Syndrome-Clinical Review,

Biological Background and Related

Disorders. Genes 2022, 13, 335.

https://doi.org/10.3390/

genes13020335

Academic Editor: Gudrun Rappold

Received: 30 December 2021

Accepted: 8 February 2022

Published: 11 February 2022

Publisher's Note: MDPI stays neutral with regard to jurisdictional claims in published maps and institutional affiliations.

Copyright: (C) 2022 by the authors. Licensee MDPI, Basel, Switzerland. This article is an open access article distributed under the terms and conditions of the Creative Commons Attribution (CC BY) license (https:// creativecommons.org/licenses/by/ $4.0 /)$.
1 Clinical Genetics Unit, Fondazione IRCCS Ca' Granda Ospedale Maggiore Policlinico, 20122 Milan, Italy; berardo.rinaldi@policlinico.mi.it (B.R.); roberta.villa@policlinico.mi.it (R.V.)

2 Experimental Research Laboratory of Medical Cytogenetics and Molecular Genetics, Istituto Auxologico Italiano, IRCCS, 20145 Milan, Italy; a.sironi@auxologico.it (A.S.); finelli@auxologico.it (P.F.)

3 Department of Medical Biotechnology and Translational Medicine, Università degli Studi di Milano, Segrate, 20090 Milan, Italy

4 Clinical Genetics Unit, Azienda USL-IRCCS of Reggio Emilia, 42123 Reggio Emilia, Italy; livia.garavelli@ausl.re.it

* Correspondence: mariafrancesca.bedeschi@policlinico.mi.it

+ These authors contributed equally to this work.

\begin{abstract}
Smith-Magenis syndrome (SMS) is a complex genetic disorder characterized by distinctive physical features, developmental delay, cognitive impairment, and a typical behavioral phenotype. SMS is caused by interstitial 17p11.2 deletions (90\%), encompassing multiple genes and including the retinoic acid-induced 1 gene (RAI1), or by pathogenic variants in $R A I 1$ itself $(10 \%)$. RAI1 is a dosage-sensitive gene expressed in many tissues and acting as transcriptional regulator. The majority of individuals exhibit a mild-to-moderate range of intellectual disability. The behavioral phenotype includes significant sleep disturbance, stereotypes, maladaptive and self-injurious behaviors. In this review, we summarize current clinical knowledge and therapeutic approaches. We further discuss the common biological background shared with other conditions commonly retained in differential diagnosis.
\end{abstract}

Keywords: Smith-Magenis; SMS; RAI1; 17p11.2 deletion syndrome; sleep disorders

\section{Introduction}

Smith-Magenis syndrome (SMS; OMIM \#182290) is a rare genetic disorder characterized by developmental delay (DD)/intellectual disability (ID), typical behavioral characteristics, distinct facial features evolving with age, and multiple congenital anomalies [1-3].

The first report of SMS was in 1982 by Ann CM Smith who described two individuals with an interstitial deletion of the p11 band on chromosome 17 [4]. Four years later, Ann Smith and Ellen Magenis expanded the previous work including nine unrelated patients and delineating the phenotypic spectrum of this condition [2], later named SMS.

The syndrome is caused either by the recurrent $17 \mathrm{p} 11.2$ deletion or pathogenic variants in $R A I 1$ causing its haploinsufficiency [2,5]. The majority of subjects carry a 17p11.2 deletion whereas the remaining ones show a pathogenic variant in RAI1 [6]. RAI1 encodes a protein that acts as transcriptional regulator and is involved in neurodevelopment, behavioral function, and circadian rhythms, such as the sleep-wake cycle.

Almost all patients reported to date are sporadic, although rare familial clustering has been described as well. Since the identification of RAI1 as the major gene of SMS [5], an increasing number of pathogenic variants have been detected in individuals presenting with the core phenotype of SMS and no 17p11.2 deletion.

The birth incidence is estimated to be between 1:15.000 [7] to 1:25.000 [3], with no predominance of either sex [8]. 
This review focuses on the current knowledge of the clinical features of SMS, with particular attention to behavioral problems and their treatment options, as well as the molecular aspects providing an overview of the spectrum of SMS-related disorders.

\section{Clinical Features}

\subsection{General Appearance}

The facial appearance could be enough recurrent and specific to prompt a gestalt recognition (Figure 1A,B). Typical dysmorphisms include brachycephaly (HP:0000248), broad face (HP:0000283), frontal bossing (HP:0002007), synophrys (HP:0000664), upslanting palpebral fissures (HP:0000582), deep-set eyes (HP:0000490), midface retrusion (HP:0011800), depressed nasal bridge (HP:0005280), short and broad nose (HP:0003196, HP:0000445), low-set and/or abnormally shaped ears (HP:0000369, HP:0000377), everted and tented upper lip vermilion (HP:0010803, HP:0010804), prognathism (HP:0000303) [1-3,9]. Other signs reported less consistently are thick hair with sparse temporal scalp distribution, thick eyebrows, eyelash trichomegaly, telecanthus/hypertelorism or hypotelorism, epicanthus, strabismus, cleft lip and/or palate, downturned corners of mouth, micrognathia (during infancy) [1,2,8-14]. The facial traits become progressively more pronounced from childhood to adulthood, particularly due to the disproportion between the midface retrusion and the increasing width and protrusion of the mandible, emphasizing prognathism $[1,10,15]$. This transition illustrates also why facial dysmorphisms of SMS may recall Down syndrome in infancy (brachycephaly, broad face with midface retrusion, upslanting palpebral fissures, short nose) [1,15] and fragile $X$ syndrome in adulthood (prognathism) [16]. Dental development is often affected, leading to malocclusion, taurodontism, and teeth agenesis, especially of the second lower premolars [17]. The voice may be peculiar and is usually described as hoarse, low-pitched, and raspy [2,3,18-20]. Hands and feet are broad, short, and associated with brachydactyly (Figure 1C,D). Clinodactyly of the fifth fingers, 2-3 toe syndactyly, single transverse palmar crease, and finger pads may also be present; polydactyly has been reported twice [2,21-25]. Common dermatological features comprise xerosis, folliculitis of the back, acral pachydermia, and plantar keratoderma [12]. Some authors have noticed that the pigmentation of hair and skin of SMS individuals is lighter than that of their relatives [12,15].
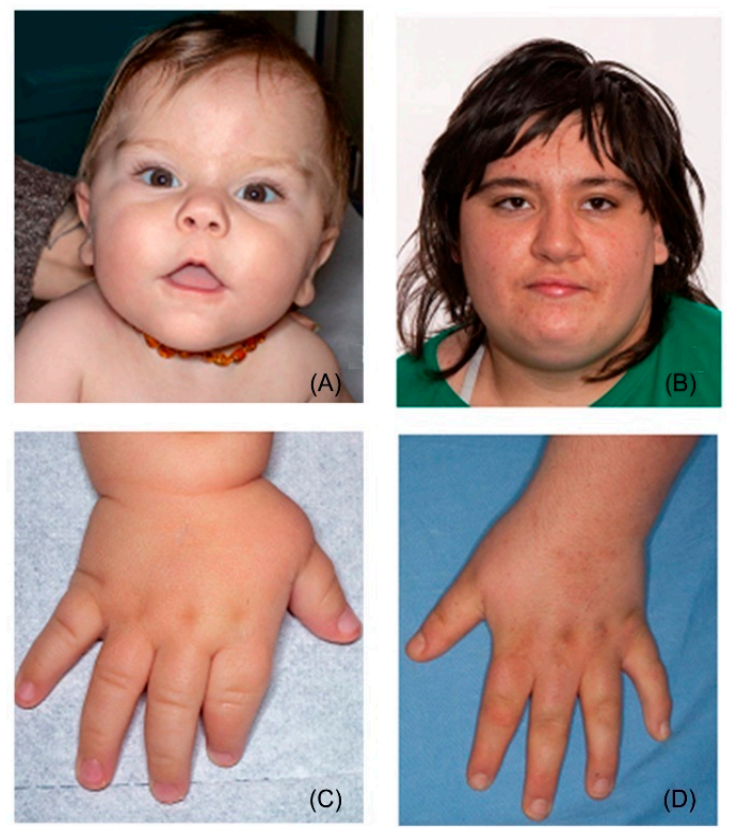

Figure 1. Main clinical anomalies in SMS: Classic facial phenotype in child (A) and in adolescence (B). Typical small hand with brachydactyly $(\mathbf{C}, \mathbf{D})$. 


\subsection{Growth}

At birth, auxological parameters usually fall within the normal range $[2,15,25]$. The evolution of weight tends to be biphasic: in the first years of life, feeding difficulties may even cause failure to thrive whereas, from preadolescence onwards, overeating, low daily activity, and possible iatrogenic side effects often cause a significant ponderal gain $[2,3,15,25,26]$. From the age of 9 years, about half $(47.8 \%)$ of individuals have a weight $>95$ th percentile [27]. Stature is usually below the normal range in toddlerhood and early childhood while it partially recovers with age $[3,21]$. Most of available data concerning height derive from series enriched in individuals in their middle/late childhood, so that the high prevalence of short stature (range 66\% [28]-81\% [3]) might not reflect the final height, which should place in the low percentiles of the normal range [29]. Moreover, a recent retrospective study found short stature to be less frequent than previously thought $(25 \%)$ [25]. When addressing adults with SMS, short stature is reported to be present in $5-10 \%$ of them [15]. Moreover, both height and weight vary accordingly to the underlying genetic defects. In particular, short stature is more documented in patients carrying the 17 p11.2 microdeletion than in those with RAI1 pathogenic variants ( $81 \%$ vs. $10 \%$ ) [8]. Short stature is not usually due to an impaired functioning of the growth hormone (GH) axis. The total secretion of GH has been proved to be normal, although the peak values were lower than those of controls [30]. On the other hand, a GH deficit was identified three times $[25,31,32]$ and replacement therapy might have proved to be effective for the final stature only once [32], requiring further studies to elucidate its real benefit. Microcephaly is not common and varies from $16 \%$ [25] to $37.5 \%$ [33].

\subsection{Multisystemic Manifestation}

Cardiovascular. The frequency of congenital heart defects (CHDs) varies from $25 \%$ [34] to $45 \%$ [28]. The most frequent CHDs are atrial septal defects, ventricular septal defects, tetralogy of Fallot, valvular abnormalities, and total anomalous pulmonary venous connection [34]. Arrhythmias and conduction disorders are present in $12 \%$ of subjects and include right conduction delay and ventricular pre-excitation [9,34]. Importantly, echographic signs of dysfunction of both the right and the left ventricle have been detected in all the patients of a cohort of 24 SMS individuals, raising concerns about the possible occurrence of heart failure [34].

Genitourinary malformations are reported in 14\% [8]-35\% [9] of subjects. The following abnormalities have been pointed out $[2,9,25,28,35-39]$ : unilateral renal agenesis, ectopic kidney, abnormally small or hypertrophic kidney(s), renal dysplasia, duplex collecting system, renal pelvic ectasia, ureteropelvic junction obstruction, ureterovesical junction ectasia or obstruction, vesicoureteral reflux. Male genitals may present cryptorchidism, testicular ectopia, shawl or underdeveloped scrotum, micropenis $[2,25,33,40]$.

Otolaryngologic domain is consistently affected in SMS [9,10,28]. A specific hearing assessment performed on 97 individuals detected an overall presence of hearing loss in at least one ear in $78.9 \%$ of the cohort, the majority of them demonstrating a slight or mild impairment. Sensorineural hearing loss was the most represented, its occurrence increased in older subjects and longitudinal data revealed a progressive decline with age. On the contrary, the proportion of conductive hearing loss was higher in childhood, corresponding to a higher percentage of flat tympanograms, in turn presumably due to middle ear effusion [41]. Indeed, acute and chronic otitis media are common in children and often require ventilation tubes [10,29]. In addition to hearing loss, also hyperacusis is part of SMS and has been estimated to be as frequent as $73.5 \%$ by means of a questionnaire addressed to caregivers [41]. Velopharyngeal insufficiency (VPI) is recurrent and has been related either to the hypotonia of the orofacial district or to patent or submucous palate cleft $[9,16,28]$. VPI may lead to hypernasal speech, phonological errors, and swallowing difficulties [9,42]. When performed, laryngoscopy showed vocal cord polyps, nodules, thickening, edema, or paralysis $[9,28]$. 
Ocular. Eyes and sight are often affected [8,25,28]. Morphological anomalies mostly involve the anterior portion of the eye. Microcornea is identified in half of SMS subjects and iris abnormalities in about 2/3 of them. The iris nodules, once identified as Brushfieldlike spots, are more properly definable as Wölfflin-Krückmann spots [13]. The frequency of strabismus was reported to be $55 \%$ in a large cohort [25], ranging from $32 \%$ [13] to $81 \%$ [21] depending on the case series. Refractive defects in SMS include myopia, astigmatism, and hyperopia and should be routinely sought as they may concern up to half of the individuals [21] and be severe [14]. Cataracts and retinal detachments are likely less penetrant $[13,25]$ than previously reported [14]. Nevertheless, the occurrence of retinal detachments may increase with age, being possibly related to severe myopia or self-injurious behaviors [6].

Musculoskeletal. As for many other genetic conditions, scoliosis and constipation are common $[8,9,21,25,28,43]$.

Immunologic. The production of antibodies is impaired in $60 \%$ of individuals, predisposing to recurrent airways infections [44].

Other less frequent findings are hypothyroidism, gastroesophageal reflux, hypercholesterolemia, and hypertriglyceridemia [15,25,45].

Malignancy. The risk of malignancies is currently considered not to be increased in SMS [6]. However, the typical 17p11.2 deletion comprises the gene $F L C N$, associated with Birt-Hogg-Dubé syndrome (BHDS, OMIM \# 135150). This autosomal dominant condition features various cutaneous alterations, spontaneous pneumothorax due to pulmonary cysts, and an increased risk for renal malignancies. A heterozygous pathogenic variant leading to loss-of-function of the FLCN gene is required for the diagnosis [46]. Although subjects diagnosed with SMS due to 17p11.2 deletions do not automatically receive an additional diagnosis of BHDS, few anecdotal patients illustrate clinical overlaps between these two conditions [47-50], raising questions about the opportunity to adopt the oncologic surveillance recommended for BHDS also for SMS.

\subsection{Neurodevelopmental Features}

SMS belongs to genetically determined neurodevelopmental disorders. This condition typically shows the co-occurrence of $\mathrm{DD} / \mathrm{ID}$, unique behavioral phenotype, and sleep disturbances.

First concerns about psychomotor development arise by the first year [25]. Hypotonia, lethargy, increased daytime sleepiness and napping, and oromotor dysfunction with reduced vocal production (crying, babbling, vocalizing) are virtually present in all infants. Feeding difficulties are also common and, in the first months, infants often need to be actively awakened during nighttime. This presentation has been summarized in the formula "quiet babies sleeping poorly" whereas the parents might refer to them as "perfect babies" $[15,19]$. Developmental milestones are delayed. Deambulation is reached on average from 20 to 25 months and first words appear in about two-thirds of individuals by the age of 3 years [25,51]. Speech delay is more severe in the expressive than in the receptive domain, so toddlers may recur to nonverbal communication. Daytime and nighttime toilet training are, respectively, achieved by $78 \%$ and $35 \%$ of children before thirteen years [25]. The degree of ID ranges from profound to borderline; the majority of subjects score in the moderate ID level $[9,25,51-55]$. At school, SMS children demonstrate longterm memory, perceptual skills and closure as points of strength while they have relevant weaknesses in short-term memory, sequential processing, and math skills [19,53,55-57]. Moreover, scholastic performance is often lowered by maladaptive conduct, hyperactivity, and distractibility $[19,58]$.

The presence of speech delay and stereotypes may recall what is commonly observed in autism spectrum disorder (ASD) $[25,51,54]$. This overlap is possibly more compelling in toddlerhood, particularly due to poor verbal communication compared to peers [51]. Contrary to what is expected in ASD, in SMS autistic features may be more penetrant in females than in males [59,60]. In a cohort of 20 minors (age range: 4-18) assessed by 
means of questionnaires addressed to their parents (Social Responsiveness Scale), 90\% of subjects scored within ASD, of whom 35\% were in the mild/moderate range and 55\% were in the severe one [59]. Nevertheless, the subsequent appearance of language, the remarkable communication and socialization skills, and the typical behavioral phenotype may distinguish SMS from typical ASD [54,61]. Another contact point between ASD and SMS is represented by the abnormal processing and modulation of environmental stimuli, including tactile and auditory aversion, hypersensitivity to sounds, vestibular and oral motor dysfunction $[15,41,62]$.

\subsection{Behavioral Manifestations}

Behavioral manifestations are heterogeneous and reflect the integration of self-injurious, stereotypic, and maladaptive components.

Their penetrance and severity are influenced by several determinants, e.g. age, sleep, communicative skills, cognitive level, developmental comorbidities, environmental context, and the underlying genetic defect $[8,21,30,51,52,54,58,63-69]$. When the diagnostic process was less straightforward, many subjects were diagnosed with psychiatric disorders, attention deficit hyperactivity disorder (ADHD), or ASD before the diagnosis of SMS was reached $[15,59]$. Self-injurious behaviors are nearly constant, being observed in more than $95 \%$ of individuals $[64,69]$. The first episodes can be appreciated from the age of 18 months, when repetitive (tilting head, body rocking, rubbing surfaces, excessive mouthing, clapping hand) and self-injurious (self-hitting, biting, or pinching, head banging, hair pulling) behaviors emerge. Onychotillomania (nail yanking) and polyembolokoilamania (insertion of objects into bodily orifices) are specific and strongly evocative of SMS. Onychotillomania and polyembolokoilamania are respectively present in $53.5 \%$ and $32.3 \%$ of subjects [70] and their occurrence increase with age $[63,64]$. Polyembolokoilamania can involve ears $(31 \%)$, nose $(17.2 \%)$, rectum $(3.5 \%)$, or vagina $(21.1 \%)$ [64]. Two additional stereotypies distinctive of SMS are the spasmodic upper-body squeeze (or self-hugging) [71] and the "lick and flip" repetitive page turning [56,63], found in approximately $51 \%$ and $46 \%$ of patients [63]. Other frequent behavioral problems are teeth grinding, screaming, temper tantrum, hetero-aggressive outbursts, and destruction of property $[56,63,70]$. On the other hand, adaptative scales show higher scores in communication and socialization skills, both in children and in adults $[52,54,66]$. This finding reflects the notion of a few individuals with SMS being particularly affectionate, communicative, eager to please but also attention seeking and unceasing talkers $[66,67,71]$. This attitude coexists with a significant emotional immaturity, which may trigger behavioral responses and make social inclusion difficult. This contrast, termed developmental asynchrony, becomes more appreciable and divergent in those with higher cognitive functioning and in adults: if academic achievements in SMS correspond to the 6- to 8-year-old range, emotional reactions are more in accordance with the 1- to 3-year-old developmental level (the so-called "inner toddler") [67].

Similarly, daily living skills seem to configure a negative correlation with age, so that in adulthood routine needs appear too demanding in respect of age or, possibly, of ID degree [53,54]. Adults generally rely on their caregivers and only a minority of them are reported to be independent in personal hygiene, cleaning tasks, cooking, or walking short distances in a familiar environment [53].

Eating disorders (foraging and overeating) appear with adolescence [70] and have been found to be directly mediated by RAI1 haploinsufficiency [27]. These traits are shared with Prader-Willi syndrome, which indeed represents another differential diagnosis due to the presence of infantile hypotonia, short stature, small hands and feet, self-picking, sleep, and behavioral problems [72].

\subsection{Sleep Disorders}

Sleep disorders were mentioned since the first reports of SMS $[2,3,33]$ and their penetrance is nearly complete $[8,21,28,73]$. The most recurrent features of sleep disturbance are fragmented and shortened sleep cycles, frequent nocturnal and early morning awakenings, 
and excessive daytime sleepiness [30,73-75]. Nighttime sleep may be further deteriorated by the occurrence of enuresis, snoring, and bruxism [73]. Reduced sleep time (on average $1 \mathrm{~h}$ less) can be detected by the first year and parents may notice increased somnolence from 12-18 months of age [15]. Interestingly, the circadian rhythm of melatonin secretion is inverted in most SMS patients [30], being active during the daytime rather than nighttime. This reversal, however, is currently not believed to be the only factor responsible for sleep disorders, which are detectable also in individuals with normal melatonin secretion [76,77]. Moreover, the circadian rhythm of body temperature is disrupted, being not inverted but shifted by about three hours in advance [74]. The employment of polysomnography revealed REM sleep to be altered in about half of individuals, resulting mostly reduced but also absent or increased [3,9]. Although sleep disorder persists throughout the entire life, some changes have been identified in the transition toward adulthood. A questionnairebased study detected an association between older ages and earlier wake-up times, more naps with shorter duration, increased number of nighttime awakenings, and shorter overall sleep time [73]. A subsequent paper employing wrist actigraphy identified an age-related variation in sleep patterns, waking time, progressively getting later, and waking time after sleep onset [74].

\subsection{Neurological Problems}

Seizures are estimated to occur in 11-30\% of subjects [3,9]. More recent series substantially confirm this proportion, ranging from $2.1 \%$ [25] to $27.5 \%$ [8]. An additional $20-25 \%$ of individuals develop electroencephalographic abnormalities without a clinical correlation $[9,15,78]$. No seizure type or electroencephalographic pattern appears to be recurrent, although focal onset impaired awareness seizures (formerly defined complex partial seizures) might occur more frequently [15]; catamenial seizures have been noticed as well [15]. Peculiar neuroradiological findings have been identified in about half of the individuals [9,25], and those more consistent are ventriculomegaly [9,15,25,79-81], anomalies of the posterior fossa (enlarged posterior fossa, mega cisterna magna) $[9,15,79,80,82]$, and bilateral decrease in grey matter concentration in lenticulo-insular regions [79]. Several sporadic abnormalities have also been highlighted: unilateral dystrophic calcification of the frontal lobe [9], cortical atrophy [25], hypoplasia of the corpus callosum [25], bilateral periventricular nodular heterotopias [82], hypoplasia of the cerebellar vermis $[9,80,81]$, hypoplasia of the pons [80], enlarged foramen magnum [9], prominent cerebrospinal fluid spaces [9]. Stroke-like episodes have been identified in three subjects, of whom one affected from Moya-Moya disease [29,83,84]; it has thus been recommended to assess cerebrovascular disease in all individuals with SMS before open-heart surgery [84]. The occurrence of peripheral neuropathy, once reported in about $75 \%$ of patients [9] and more recently estimated at 38\% [25], may produce reduced deep tendon reflexes, a peculiar profile of lower limbs (i.e., the inverted champagne bottle appearance), abnormal gait (flapping feet, toe walking), pes cavus or pes planus [9,15]; moreover, the decreased sensitivity to temperature and pain may worsen the consequences of self-injurious behaviors and polyembolokoilamania [19].

\section{Genomic and Genetic Cause of SMS}

The most common genetic cause of SMS, accounting for about $90 \%$ of patients, is an interstitial deletion at $17 \mathrm{p} 11.2$, ranging from 1.5 to $9 \mathrm{Mb}[5,21]$. About $70-80 \%$ of the individuals with a 17p11.2 deletion carry a large and recurrent deletion of $3.7 \mathrm{Mb}$, which results from non-allelic homologous recombination (NAHR) between low-copy-number repeats (LCR) [28,85]. 17p11.2 is a rearrangement-prone genomic region containing seven LCR elements [86]. The genomic instability of this region derives also from the presence of repetitive elements such as Alu elements and AT-rich repeats, that through NAHR and non-homologous end joining (NHEJ) mechanisms are causative of the remaining 20-25\% of SMS patients that display atypical deletions of variable size [87]. 
About 80 known genes map to the 17p11.2 deleted region and for a long time, SMS has been considered a contiguous gene syndrome [3]. Subsequently, the sequence analysis in three patients with SMS phenotype lacking the common deletion disclosed frame-shift variants in RAI1 (retinoic acid-induced 1), demonstrating its role as the causative gene for SMS [5].

Up to now, about 50 pathogenic variants, mostly non-sense and in-frame located in exon 3 (http:/ / www.hgmd.cf.ac.uk/ac/all.php (accessed on 15 December 2021), HGMD Professional, version 3 September 2021), have been detected in $10 \%$ of patients with classical SMS clinical features (Figure 2). All the identified variants result in RAI1 haploinsufficiency, which is responsible for the SMS phenotype.

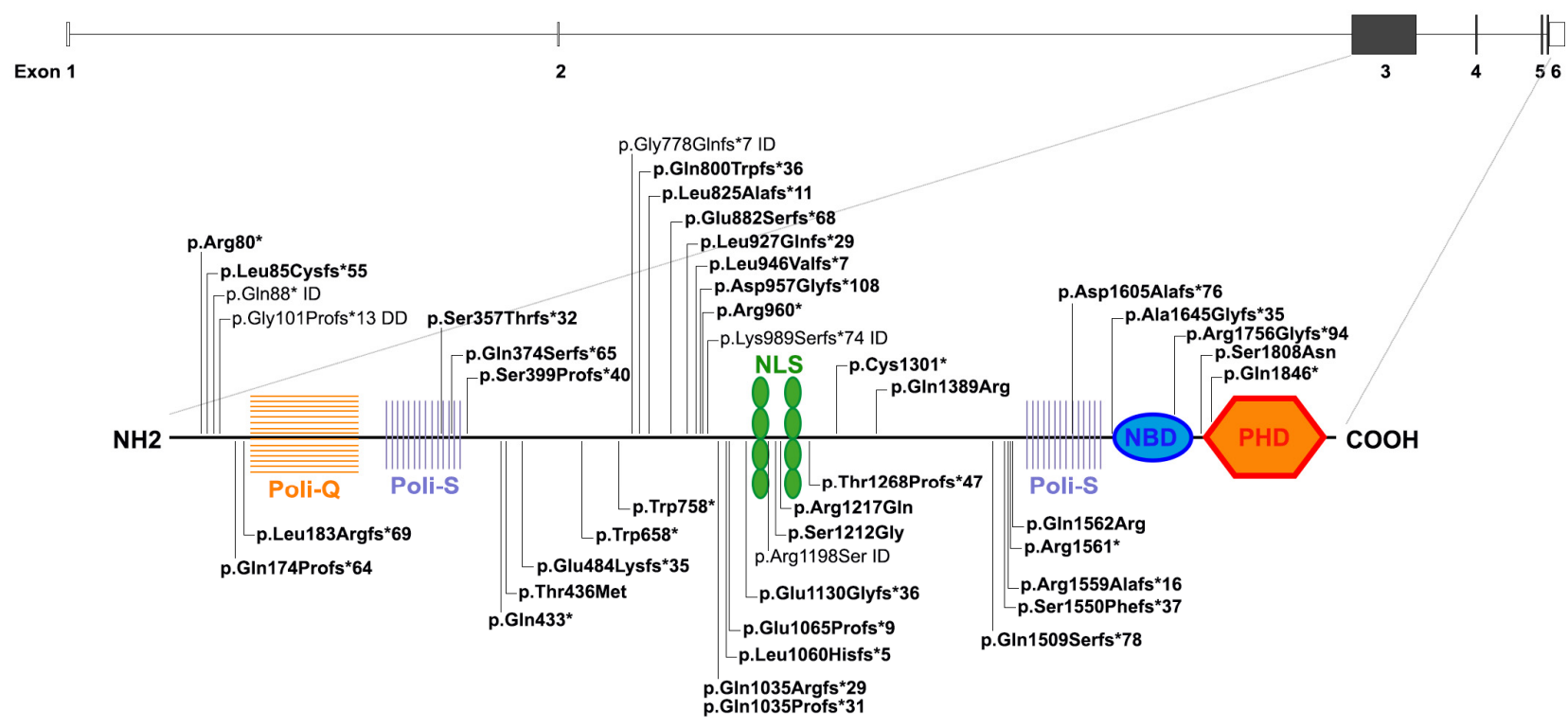

Figure 2. RAI1 gene and protein structures. At the top, RAI1 gene structure based on RefSeq NM_030665, including noncoding exons (white) and coding regions (dark grey). At the bottom, RAI1 protein structure with seven key functional domains, starting with $\mathrm{N}$-terminal a polyglutamine rich tract (Poly-Q, orange), a polyserine rich domain (Poly-S, light purple), a bipartite Nuclear Localization Signal (NLS, green), a second Poly-S tract (light purple), a nucleosome-binding domain (NBD, blue), and a C-terminal "plant homeo-domain" (PHD, red). The pathogenic SMS-associated reported truncating and missense mutations are indicated in bold in the protein structure, the remaining variations reported are not associated with SMS, but with indicated conditions, according to HGMD Professional (version 3 September 2021) and ClinVar database. ID; intellectual disability, DD; developmental delay.

A recent study on a large SMS cohort evidenced a higher number of pathogenic variants in RAI1 than previously reported (23\% compared to $10 \%$ of all patients with SMS [86]), suggesting that the percentage of RAI1 variants causing SMS is underestimated [88]. This finding can firstly be explained by the fact that a multisystemic disorder may not be suspected in patients with RAI1 variants due to the reduced penetrance of congenital anomalies, commonly associated with 17 p11.2 deletions. Indeed, notwithstanding the consistent phenotypic overlap among patients harboring either the 17p11.2 classical deletion or a pathogenic variant in RAI1, cardiac and renal anomalies, motor delay, short stature, and hearing loss are enriched in carriers of the 17p11.2 deletion [8,21]. Conversely, patients carrying RAI1 variants show an increased risk of developing overweight/obesity, feeding disorders, polyembolokoilamania, self-hugging, skin picking, muscle cramping, and dry skin $[8,11,21]$. Secondly, agnostic genetic testing for patients not resembling classical SMS was introduced only recently by means of next-generation sequencing (NGS) technology, 
which will likely lead to an increased detection of RAI1 pathogenic variants, with clinical implications for genetic counseling and decision making [89].

SMS is an autosomal dominant condition typically caused by de novo deletions or pathogenic variants in RAI1 at 17p11.2, although familial transmission has been observed [90-92]. Zori and collaborators identified a maternal mosaicism for 17p11.2 deletion [90]; other SMS cases of parental mosaicism are known, including one family with three affected sibs due to maternal mosaicism [92]. Even rare complex chromosome rearrangements leading to 17p11.2 deletion have been reported [91,93,94]. In 2017, for the first time, a SMS individual harboring an RAI1 frameshift variant gave birth to a child with the same genotype [95].

RAI1 (OMIM *607642, NM_030665) is composed of six exons, four of which are protein coding, and is widely expressed among tissues, including the brain. RAI1 is highly conserved across different species and is composed of seven different functional domains (Figure 2) [96-100]. Among them there is a C-terminal "plant homeo-domain" (PHD) containing a His-Cys5-His-Cys2-His motif, an extremely conserved motif distinctive of nuclear proteins implicated in chromatin remodeling and in transcriptional regulation [101-103]. Indeed, RAI1 is a transcriptional regulator that enhances the expression of many genes involved in the development and function of the mammalian brain, for instance implicated in the homeostasis maintenance of synaptic plasticity [104] and regulation of circadian rhythm $[100,105,106]$.

RAI1 is classified within epigenetic machinery readers [106] and likely binds to unmodified histone tail $\mathrm{H} 3$ through the PHD domain. In addition, proteomic studies suggest that RAI1 may interact with PHF14, TCF20, HMG20A/iBRAF, which contain several PHD domains as well [107]. Supported by these findings, it was proposed that together they might form a multiprotein complex, the "RAI1 complex", functioning as chromatin reader specifically recognizing and binding unmethylated lysine 4 of histone 3 (H3K4) and recruiting MLL1 (KMT2A, OMIM *159555) to tri-methylate H3K4, thereby promoting gene transcription [106]. The biological relevance of these proteins is highlighted by the clinical consequences of their haploinsufficiency, as KMT2A and TCF20 are the causative genes of Wiedemann-Steiner syndrome (WDSTS, OMIM \#605130) and of a syndromic neurodevelopmental disorder (OMIM \#618430), respectively [108,109].

At the moment, very little is known about the transcriptional regulatory activity and the target genes of RAI1. However, the genome-wide testing approach on SMS-like patients without molecular diagnosis has provided some clues.

\section{Differential Diagnosis and Related Disorders}

Only $50 \%$ of individuals with a clinical suspicion of SMS have been confirmed by genetic tests, suggesting that other loci may be directly or indirectly involved in the same pathway of RAI1, hence contributing to SMS-like phenotype (Figure 3) [86]. The best approach to discover and understand the molecular basis of complex disorders is by means of genome-wide investigation, such as array-CGH and NGS. Array-CGH screening in SMS-like patients, displaying most of SMS clinical features but lacking either the classical 17p11.2 deletion or RAI1 mutations, disclosed HDAC4 and MBD5 loss-of-function alterations $[110,111]$.

HDAC4 is a class IIa histone deacetylase. Interestingly, quantitative expression analysis on BDMR (BrachyDactyly-Mental Retardation syndrome, OMIM \#600430) patients, carrying either a deletion including $H D A C 4$ or $H D A C 4$ mutations, resulted in the downregulation of RAI1 transcripts [110], suggesting that HDAC4 plays a role as RAI1 transcriptional regulator. This evidence supports their possible connection and may explain the overlapping phenotypes of SMS and BDMR. The second SMS-related locus is 2q23.1, the region involving the $M B D 5$ gene [111,112]. Deletions or loss-of-function variants of MBD5 cause MBD5-associated neurodevelopmental disorder (MAND; OMIM \#156200). A downregulation of RAI1 was detected in MAND patients, thus supporting the idea that MBD5 might also exert control on RAI1 transcription [113]. Moreover, similarly to SMS, MAND 
patients show sleep disorders and, in patient-derived lymphoblastoid cell lines, MBD5 haploinsufficiency was demonstrated to lead to the downregulation of clock circadian genes (CCG) (PER1, PER2, PER3, NR1D2, CRY2) and RAI1, thus linking circadian rhythm disruption to RAI1 expression [114].

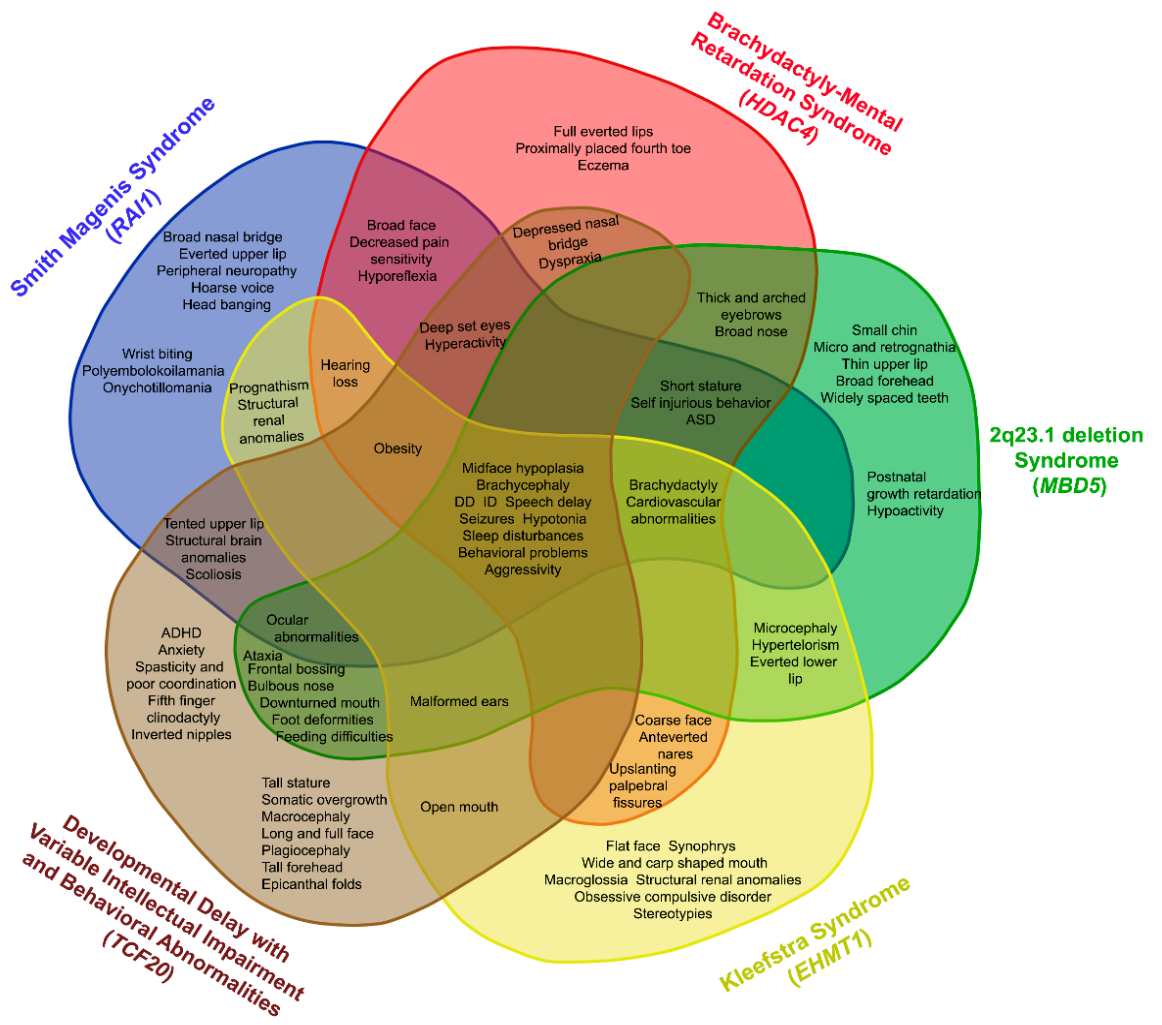

Figure 3. Venn diagram showing common and specific clinical features of SMS-overlapping disorders (2q23.1 deletion, BDMR, KS, and DDVIBA). ID-intellectual disability, DD-developmental delay, ASD-autism spectrum disorder.

In addition, pathogenic de novo variants in $M B D 5$ and in other epigenetic regulators (SMARCB1, NR1I3, KMT2C) were reported in individuals with a clinical diagnosis of Kleefstra syndrome (KS; OMIM \#610253) [115,116]. This condition, also known as 9q34.3 deletion syndrome, is due to microdeletions or point variants of the EHMT1 gene [117]. EHMT1 encodes a histone methyltransferase, which is considered a histone writer mono- and di-methylating H3K9 (histone 3 lysine 9) and is involved in chromatin remodeling during neurodevelopment and synaptic plasticity [118]. Moreover, the increase of H3K9me2/3 correlates with altered expression of protocadherins, principal regulators of cell-cell adhesion and neuronal connectivity associated with ASD etiology [119]. Although a direct molecular link between RAI1 and EHMT1 remains to be proved, the clinical overlap of SMS and KS might be mediated by MBD5.

Whole-exome sequencing (WES) performed in individuals with a clinical suspicion of SMS but without a molecular diagnosis highlighted potentially deleterious variants in different genes, including KMTD2, MECP2, KDM5C, IQSEC2, and DEAF1 [120,121]. Notably, a combined approach using WES and array-CGH in 31 unrelated families with an SMS-like phenotype identified pathogenic variants in TCF20, defining a new syndrome termed developmental delay with variable intellectual impairment and behavioral abnormalities (DDVIBA, OMIM \#618430). These findings support the commonalities in gene structure and function between TCF20 and RAI1, reinforcing the role of the "RAI1 complex", of which both are likely part, and likely explaining the shared core clinical features [122]. Based on routine and dedicated genetic analysis, we suggest a diagnostic algorithm for the diagnosis of SMS and SMS-related disorders (Figure 4). 


\section{MOLECULAR ANALYSIS FLOWCHART}

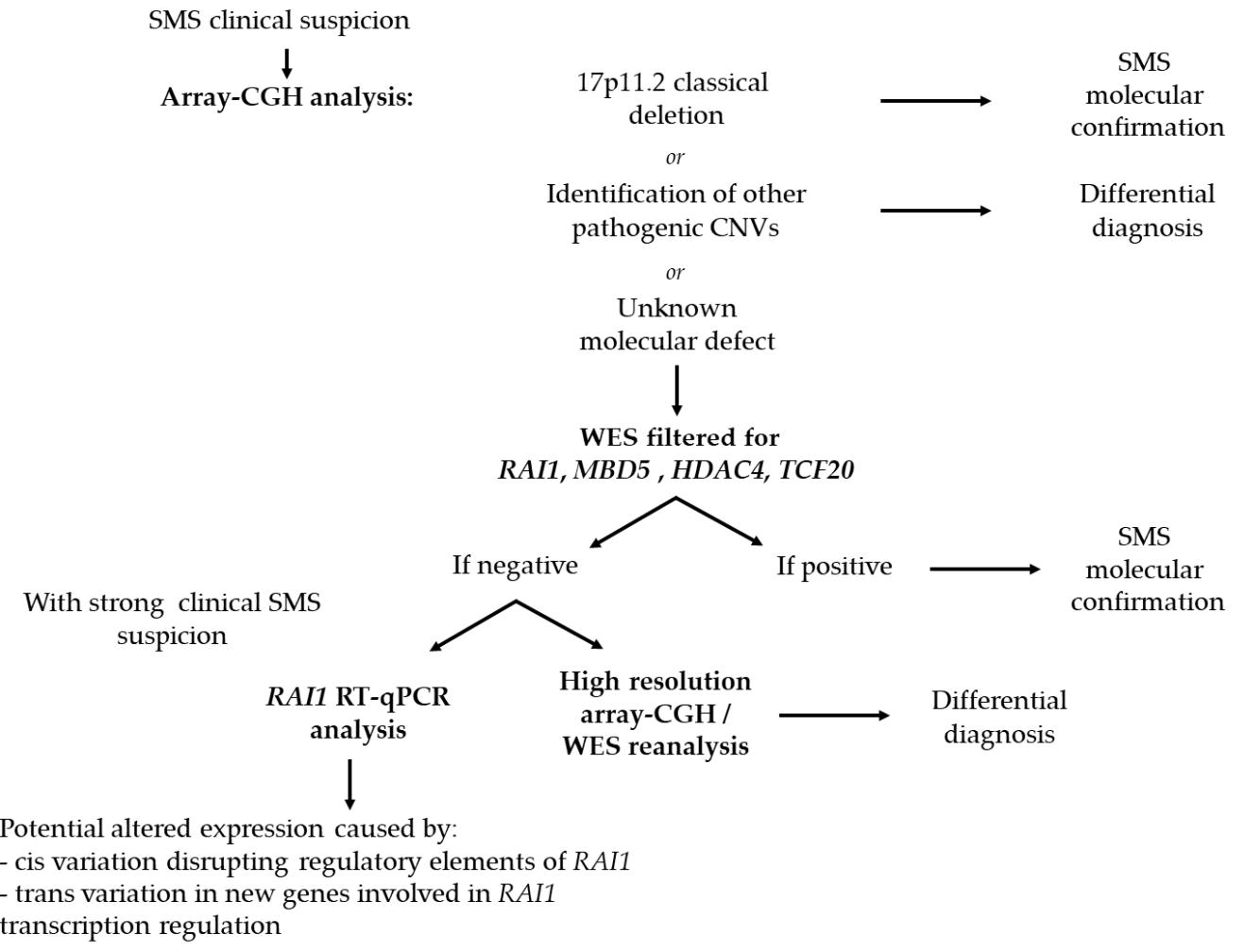

Figure 4. Suggested diagnostic approach for SMS.

Genome-wide methylation episignatures are significant tools to improve the diagnostic process and provide functional clues. The clinical overlap among SMS and the mentioned conditions does not currently find an epigenetic counterpart, as distinctive episignatures have been detected for HDAC4, MBD5, MLL1/KMT2A but not for RAI1 [123,124].

Despite these functional and clinical convergences, further studies are needed to explore on different omic levels the functional links among these genes and clarify the biological mechanisms responsible for their phenotypic overlap.

\section{Treatment Insight}

To date, no specific therapy is available for SMS; therefore, its clinical management consists of treating the medical issues presented by each affected individual. Appropriate assessment of related clinical problems, early target intervention, and strict maintenance to therapy can improve overall health, quality of life, and social functioning in SMS patients.

Considering that nearly all SMS individuals have behavioral problems and sleep disturbance, treatments focus on behavioral and educational interventions that target these cardinal traits. Psychotropic medications may be necessary, although evidence regarding pharmacological interventions in SMS is scarce. The array of medications that are prescribed in clinical practice appears to be largely based on clinical experience, case reports, or small series assessing drug efficacy on autism in general and/or ADHD.

According to the retrospective study of Laje et al. [125], stimulants are the preferred medications in the treatment of hyperactivity symptoms. In particular, methylphenidate $(\mathrm{MPH})$ is well-established as first-line treatment with high efficacy and tolerability compared to other psychotropic drugs [126]. Clonidine is sometimes used for the treatment of ADHD in addition or in alternative to stimulants and may have a beneficial effect on sleep in that population [125]. Among the antipsychotics, risperidone shows a marked improvement of symptoms of hyperactivity and/or maladaptive behaviors (including 
irritability, aggression, outbursts, and self-injury) [127,128]. Adverse effects of risperidone include weight gain, increased appetite, hyperlipidemia, insulin resistance, fatigue.

Furthermore, the management of dysfunctional sleep patterns should also be considered as a key clinical goal in SMS subjects. Good sleep hygiene should include maintaining regular day and night routines, developing rituals that help with relaxation, keeping the sleep environment dark during the night, pleasant and relaxing, and avoiding caffeine and electronic devices. However, pharmacotherapy is often required to optimize the routine management of sleep disorders. Melatonin is a common nonprescription pharmacologic treatment particularly appropriate for populations with sleep disturbance due to circadian phase delay, as for SMS. Evidence to support the use of short-acting melatonin supplementation consists of small case series and anecdotal reports by SMS parents. Overall, short melatonin treatment trials reported a significant decrease in sleep latency with little impact on the total duration of sleep or behavioral manifestations. Optimal melatonin dosing ranged from 0.75 to $10 \mathrm{mg}$ /day taken approximately $90 \mathrm{~min}$ before bedtime $[129,130]$. The combined regimen of nocturnal melatonin and daytime administration of acebutolol, an adrenergic antagonist that blocks melatonin secretion, proved to be beneficial. This strategy may increase nocturnal melatonin concentrations, improve nocturnal sleep and behavior, and aid in correcting sleep patterns [131].

Tasimelteon is an oral melatonin receptor agonist that was developed for the treatment of circadian sleep-wake rhythm disorders. In 2020, this drug was approved in the US for the treatment of nighttime sleep disturbances in SMS [132]. Ramelteon, another melatonin agonist approved for the treatment of insomnia, has not been studied specifically in patients with SMS but has been shown to shift the circadian phase in individuals with jet lag [133] and might be effective also in SMS.

Other drugs that could be useful in the management of sleep problems in children with SMS include antihistamines (i.e., diphenhydramine), antidepressants (i.e., trazodone), atypical antipsychotics (i.e., quetiapine), gabapentin, or other anticonvulsant drugs (appropriate for children with concomitant seizure disorders) [129].

Author Contributions: Writing-original draft preparation, B.R., R.V. and A.S.; L.G. contributed to review; writing - review and editing, P.F. and M.F.B.; supervision, P.F. and M.F.B. All authors have read and agreed to the published version of the manuscript.

Funding: This research received no external funding.

Institutional Review Board Statement: Not applicable.

Informed Consent Statement: Not applicable.

Data Availability Statement: Data sharing not applicable.

Acknowledgments: This work has been generated within the European Reference Network on Rare Congenital Malformations and Rare Intellectual Disability (ERN-ITHACA) (EU Framework Partnership Agreement ID: 3HP-HP-FPA ERN-01-2016/739516). This study was supported by the Italian Ministry of Health grants 'Ricerca Corrente' (08C302_2013 and 08C725_2017) provided to IRCCS Istituto Auxologico Italiano.

Conflicts of Interest: The authors declare no conflict of interest.

\section{References}

1. Allanson, J.E.; Greenberg, F.; Smith, A.C.M. The Face of Smith-Magenis Syndrome: A Subjective and Objective Study. J. Med. Genet. 1999, 36, 394-397. [CrossRef] [PubMed]

2. Smith, A.C.M.; McGavran, L.; Robinson, J.; Waldstein, G.; Macfarlane, J.; Zonona, J.; Reiss, J.; Lahr, M.; Allen, L.; Magenis, E. Interstitial Deletion of (17)(p11.2p11.2) in Nine Patients. Am. J. Med. Genet. 1986, 24, 393-414. [CrossRef] [PubMed]

3. Greenberg, F.; Guzzetta, V.; De Oca-Luna, R.M.; Magenis, R.E.; Smith, A.C.M.; Richter, S.F.; Kondo, I.; Dobyns, W.B.; Patel, P.I.; Lupski, J.R. Molecular Analysis of the Smith-Magenis Syndrome: A Possible Contiguous-Gene Syndrome Associated with $\operatorname{del}(17)(\mathrm{p} 11.2)$. Am. J. Hum. Genet. 1991, 49, 1207-1218.

4. Smith, A.C.M.; McGavran, L.; Waldstein, G. Deletion of the 17 Short Arm in Two Patients with Facial Clefts. Am. J. Med. Genet. 1982, 34, 410A. 
5. Slager, R.E.; Newton, T.L.; Vlangos, C.N.; Finucane, B.; Elsea, S.H. Mutations in RAI1 Associated with Smith-Magenis Syndrome. Nat. Genet. 2003, 33, 466-468. [CrossRef] [PubMed]

6. Smith, A.C.M.; Boyd, K.E.; Brennan, C.; Charles, J.; Elsea, S.H.; Finucane, B.M.; Foster, R.; Gropman, A.; Girirajan, S.; Haas-Givler, B. Smith-Magenis Syndrome. In GeneReviews ${ }^{\circledR}$ [Internet]. Available online: https://www.ncbi.nlm.nih.gov/books/NBK1310/ (accessed on 9 December 2021).

7. Smith, A.C.M.; Magenis, R.E.; Elsea, S.H. Overview of Smith-Magenis Syndrome. J. Assoc. Genet. Technol. 2005, 31, 163-167. [PubMed]

8. Edelman, E.A.; Girirajan, S.; Finucane, B.; Patel, P.I.; Lupski, J.R.; Smith, A.C.M.; Elsea, S.H. Gender, Genotype, and Phenotype Differences in Smith-Magenis Syndrome: A Meta-Analysis of 105 Cases. Clin. Genet. 2007, 71, 540-550. [CrossRef]

9. Greenberg, F.; Lewis, R.A.; Potocki, L.; Glaze, D.; Parke, J.; Killian, J.; Murphy, M.A.; Williamson, D.; Brown, F.; Dutton, R.; et al. Multi-Disciplinary Clinical Study of Smith-Magenis Syndrome (Deletion 17p11.2). Am. J. Med. Genet. 1996, 62, 247-254. [CrossRef]

10. Elsea, S.H.; Girirajan, S.S. Smith-Magenis Syndrome. Eur. J. Hum. Genet. 2008, 16, 412-421. [CrossRef]

11. Girirajan, S.; Elsas, L.J.; Devriendt, K.; Elsea, S.H. RAI1 Variations in Smith-Magenis Syndrome Patients without 17p11.2 Deletions. J. Med. Genet. 2005, 42, 820-828. [CrossRef]

12. Guérin-Moreau, M.; Colin, E.; Nguyen, S.; Andrieux, J.; De Leersnyder, H.; Bonneau, D.; Martin, L. Dermatologic Features of Smith-Magenis Syndrome. Pediatr. Dermatol. 2015, 32, 337-341. [CrossRef] [PubMed]

13. Chen, R.M.; Lupski, J.R.; Greenberg, F.; Lewis, R.A. Ophthalmic Manifestations of Smith-Magenis Syndrome. Ophthalmology 1996, 103, 1084-1091. [CrossRef]

14. Finucane, B.M.; Jaeger, E.R.; Kurtz, M.B.; Weinstein, M.; Scott, C.I. Eye Abnormalities in the Smith-Magenis Contiguous Gene Deletion Syndrome. Am. J. Med. Genet. 1993, 45, 443-446. [CrossRef]

15. Gropman, A.L.; Duncan, W.C.; Smith, A.C.M. Neurologic and Developmental Features of the Smith-Magenis Syndrome (del 17p11.2). Pediatr. Neurol. 2006, 34, 337-350. [CrossRef] [PubMed]

16. Chen, K.S.; Potocki, L.; Lupski, J.R. The Smith-Magenis Syndrome [del(17)p11.2]: Clinical Review and Molecular Advances. Ment. Retard. Dev. Disabil. Res. Rev. 1996, 2, 122-129. [CrossRef]

17. Tomona, N.; Smith, A.C.M.; Guadagnini, J.P.; Hart, T.C. Craniofacial and Dental Phenotype of Smith-Magenis Syndrome. Am. J. Med. Genet. Part A 2006, 140, 2556-2561. [CrossRef] [PubMed]

18. Di Cicco, M.; Padoan, R.; Felisati, G.; Dilani, D.; Moretti, E.; Guerneri, S.; Selicorni, A. Otorhinolaringologic Manifestation of Smith-Magenis Syndrome. Int. J. Pediatr. Otorhinolaryngol. 2001, 59, 147-150. [CrossRef]

19. Smith, A.C.M.; Dykens, E.; Greenberg, F. Behavioral Phenotype of Smith-Magenis Syndrome (del 17p11.2). Am. J. Med. Genet. Neuropsychiatr. Genet. 1998, 81, 179-185. [CrossRef]

20. La Guía, I.H.D.; Garayzábal-Heinze, E.; Gómez-Vilda, P. Voice Characteristics in Smith-Magenis Syndrome: An Acoustic Study of Laryngeal Biomechanics. Languages 2020, 5, 31. [CrossRef]

21. Girirajan, S.; Vlangos, C.N.; Szomju, B.B.; Edelman, E.; Trevors, C.D.; Dupuis, L.; Nezarati, M.; Bunyan, D.J.; Elsea, S.H Genotype-Phenotype Correlation in Smith-Magenis Syndrome: Evidence That Multiple Genes in 17p11.2 Contribute to the Clinical Spectrum. Genet. Med. 2006, 8, 417-427. [CrossRef]

22. Kondo, I.; Matsuura, S.; Kuwajima, K.; Tokashiki, M.; Izumikawa, Y.; Naritomi, K.; Niikawa, N.; Kajii, T. Diagnostic Hand Anomalies in Smith-Magenis Syndrome: Four New Patients with del (17)(p11.2p11.2). Am. J. Med. Genet. 1991, 41, 225-229. [CrossRef] [PubMed]

23. Schlesinger, A.E.; Potocki, L.; Poznanski, A.K.; Lupski, J.R. The Hand in Smith-Magenis Syndrome (Deletion 17p11.2): Evaluation by Metacarpophalangeal Pattern Profile Analysis. Pediatr. Radiol. 2003, 33, 173-176. [CrossRef] [PubMed]

24. MarianneJensen, L.; Kirchhoff, M. Polydactyly in a Boy with Smith-Magenis Syndrome. Clin. Dysmorphol. 2005, 14, 189-190. [CrossRef] [PubMed]

25. Rive Le Gouard, N.; Jacquinet, A.; Ruaud, L.; Deleersnyder, H.; Ageorges, F.; Gallard, J.; Lacombe, D.; Odent, S.; Mikaty, M.; Manouvrier-Hanu, S.; et al. Smith-Magenis Syndrome: Clinical and Behavioral Characteristics in a Large Retrospective Cohort. Clin. Genet. 2021, 99, 519-528. [CrossRef] [PubMed]

26. Crain, C.A. An Assessment of Obesity and Hyperphagia in Individuals with Smith-Magenis Syndrome. Master's Thesis, University of Texas Graduate School of Biomedical Sciences, Houston, TX, USA, May 2010.

27. Burns, B.; Schmidt, K.; Williams, S.R.; Kim, S.; Girirajan, S.; Elsea, S.H. Rai1 Haploinsufficiency Causes Reduced Bdnf Expression Resulting in Hyperphagia, Obesity and Altered Fat Distribution in Mice and Humans with No Evidence of Metabolic Syndrome. Hum. Mol. Genet. 2010, 19, 4026-4042. [CrossRef]

28. Potocki, L.; Shaw, C.J.; Stankiewicz, P.; Lupski, J.R. Variability in Clinical Phenotype despite Common Chromosomal Deletion in Smith-Magenis Syndrome [del(17)(p11.2p11.2)]. Genet. Med. 2003, 5, 430-434. [CrossRef]

29. Smith, A.C.M.; Gropman, A.L. Smith-Magenis Syndrome. In Cassidy and Allanson's Management of Genetic Syndromes; John Wiley \& Sons, Inc.: Hoboken, NJ, USA, 2021; pp. 863-893.

30. De Leersnyder, H.; De Blois, M.C.; Claustrat, B.; Romana, S.; Albrecht, U.; Von Kleist-Retzow, J.C.; Delobel, B.; Viot, G.; Lyonnet, S.; Vekemans, M.; et al. Inversion of the Circadian Rhythm of Melatonin in the Smith-Magenis Syndrome. J. Pediatr. 2001, 139, 111-116. [CrossRef]

31. Itoh, M.; Hayashi, M.; Hasegawa, T.; Shimohira, M.; Kohyama, J. Systemic Growth Hormone Corrects Sleep Disturbance in Smith-Magenis Syndrome. Brain Dev. 2004, 26, 484-486. [CrossRef] 
32. Spadoni, E.; Colapietro, P.; Bozzola, M.; Marseglia, G.L.; Repossi, L.; Danesino, C.; Larizza, L.; Maraschio, P. Smith-Magenis Syndrome and Growth Hormone Deficiency. Eur. J. Pediatr. 2004, 163, 353-358. [CrossRef]

33. Stratton, R.F.; Dobyns, W.B.; Greenberg, F.; DeSana, J.B.; Moore, C.; Fidone, G.; Runge, G.H.; Feldman, P.; Sekhon, G.S.; Pauli, R.M. Interstitial Deletion of (17)(p11.2p11.2): Report of Six Additional Patients with a New Chromosome Deletion Syndrome. Am. J. Med. Genet. 1986, 24, 421-432. [CrossRef]

34. Onesimo, R.; Versacci, P.; Delogu, A.B.; De Rosa, G.; Pugnaloni, F.; Blandino, R.; Leoni, C.; Calcagni, G.; Digilio, M.C.; Zollino, M.; et al. Smith-Magenis Syndrome: Report of Morphological and New Functional Cardiac Findings with Review of the Literature. Am. J. Med. Genet. Part A 2021, 185, 2003-2011. [CrossRef] [PubMed]

35. Chou, I.C.; Tsai, F.J.; Yu, M.T.; Tsai, C.H. Smith-Magenis Syndrome with Bilateral Vesicoureteral Reflux: A Case Report. J. Formos. Med. Assoc. 2002, 101, 726-728. [PubMed]

36. Fischer, H.; Oswald, H.-P.; Duba, H.-C.; Doczy, L.; Simma, B.; Utermann, G.; Haas, O. Constitutional Interstitial Deletion of 17(p11.2) (Smith-Magenis Syndrome): A Clinically Recognizable Microdeletion Syndrome. Klin. Pädiatr. 1993, 205, 166-170. [CrossRef]

37. Al-Qudah, A.A.; El-Khateeb, M.S.; Abu-Hamour, W.; Bulos, N.K. Smith-Magenis Syndrome: Report of Two Cases and Review of the Literature. Ann. Saudi Med. 1994, 14, 417-419. [CrossRef]

38. Myers, S.M.; Challman, T.D.; Bock, G.H. End-Stage Renal Failure in Smith-Magenis Syndrome. Am. J. Med. Genet. Part A 2007, 143, 1922-1924. [CrossRef]

39. Fan, Y.-S.; Farrell, S.A. Prenatal Diagnosis of Interstitial Deletion of 17(p11.2p11.2) (Smith-Magenis Syndrome). Am. J. Med. Genet. 1994, 49, 253-254. [CrossRef]

40. Zhang, P.; Sun, Y.; Tian, H.; Rong, L.; Wang, F.; Yu, X.; Li, Y.; Gao, J. Prenatal Diagnosis and Neonatal Phenotype of a de novo Microdeletion of 17p11.2p12 Associated with Smith-Magenis Syndrome and External Genital Defects. J. Genet. 2020, 99, 50. [CrossRef]

41. Brendal, M.A.; King, K.A.; Zalewski, C.K.; Finucane, B.M.; Introne, W.; Brewer, C.C.; Smith, A.C.M. Auditory Phenotype of Smith-Magenis Syndrome. J. Speech Lang. Hear. Res. 2017, 60, 1076-1087. [CrossRef]

42. Hidalgo de la Guía, I.; Garayzábal Heinze, E. Diferencias Fonológicas Entre Síndromes Del Neurodesarrollo: Evidencias a Partir de Los Procesos de Simplificación Fonológica Más Frecuentes. Rev. Investig. Logop. 2019, 9, 81-106. [CrossRef]

43. Spilsbury, J.; Mohanty, K. The Orthopaedic Manifestations of Smith-Magenis Syndrome. J. Pediatr. Orthop. B 2003, 12, 22-26. [CrossRef]

44. Perkins, T.; Rosenberg, J.M.; Coz, C.L.; Alaimo, J.T.; Trofa, M. Smith-Magenis Syndrome Patients Often Display Antibody Deficiency but Not Other Immune Pathologies. J. Allergy Clin. Immunol. Pract. 2017, 5, 1344-1350.e3. [CrossRef] [PubMed]

45. Smith, A.C.M.; Groptnan, A.L.; Bailey-Wilson, J.E.; Goker-Alpan, O.; Elsea, S.H.; Blancato, J.; Lupski, J.R.; Potocki, L. Hypercholesterolemia in Children with Smith-Magenis Syndrome: Del (17)(p11.2p11.2). Genet. Med. 2002, 4, 118-125. [CrossRef] [PubMed]

46. Schmidt, L.S.; Linehan, W.M. Molecular Genetics and Clinical Features of Birt-Hogg-Dubé Syndrome. Nat. Rev. Urol. 2015, 12, 558-569. [CrossRef] [PubMed]

47. Truong, H.T.; Dudding, T.; Blanchard, C.L.; Elsea, S.H. Frameshift Mutation Hotspot Identified in Smith-Magenis Syndrome: Case Report and Review of Literature. BMC Med. Genet. 2010, 11, 142. [CrossRef]

48. Smith, A.C.M.; Fleming, L.R.; Piskorski, A.M.; Amin, A.; Phorphutkul, C.; de la Monte, S.; Stopa, E.; Introne, W.; Vilboux, T.; Duncan, F.; et al. Deletion of 17p11.2 Encompasses FLCN with Increased Risk of Birt-Hogg-Dubé in Smith Magenis Syndrome: Recommendation for Cancer Screening. Abstract 2603S. In Proceedings of the 63rd Annual Meeting of The American Society of Human Genetics, San Diego, CA, USA, 18-22 October 2014.

49. Dardour, L.; Verleyen, P.; Lesage, K.; Holvoet, M.; Devriendt, K. Bilateral Renal Tumors in an Adult Man with Smith-Magenis Syndrome: The Role of the FLCN Gene. Eur. J. Med. Genet. 2016, 59, 499-501. [CrossRef]

50. Finucane, B.; Savatt, J.M.; Shimelis, H.; Girirajan, S.; Myers, S.M. Birt-Hogg-Dubé Symptoms in Smith-Magenis Syndrome Include Pediatric-Onset Pneumothorax. Am. J. Med. Genet. Part A 2021, 185, 1922-1924. [CrossRef]

51. Wolters, P.L.; Gropman, A.L.; Martin, S.C.; Smith, M.R.; Hildenbrand, H.L.; Brewer, C.C.; Smith, A.C.M. Neurodevelopment of Children Under 3 Years of Age with Smith-Magenis Syndrome. Pediatr. Neurol. 2009, 41, 250-258. [CrossRef]

52. Madduri, N.; Peters, S.U.; Voigt, R.G.; Llorente, A.M.; Lupski, J.R.; Potocki, L. Cognitive and Adaptive Behavior Profiles in Smith-Magenis Syndrome. J. Dev. Behav. Pediatr. 2006, 27, 188-192. [CrossRef]

53. Udwin, O.; Webber, C.; Horn, I. Abilities and Attainment in Smith-Magenis Syndrome. Dev. Med. Child Neurol. 2001, $43,823$. [CrossRef]

54. Martin, S.C.; Wolters, P.L.; Smith, A.C.M. Adaptive and Maladaptive Behavior in Children with Smith-Magenis Syndrome J. Autism Dev. Disord. 2006, 36, 541-552. [CrossRef]

55. Garayzábal Heinze, E.; Lens Villaverde, M.; Moruno López, E.; Conde Magro, T.; Moura, L.F.; Fernández, M.; Sampaio, A. General cognitive functioning and psycholinguistic abilities in children with Smith-Magenis Syndrome. Psicothema 2011, 23, 725-731. [PubMed]

56. Dykens, E.M.; Finucane, B.M.; Gayley, C. Brief Report: Cognitive and Behavioral Profiles in Persons with Smith-Magenis Syndrome. J. Autism Dev. Disord. 1997, 27, 203-211. [CrossRef] [PubMed] 
57. Osório, A.; Cruz, R.; Sampaio, A.; Garayzábal, E.; Carracedo, Á.; Fernández-Prieto, M. Cognitive Functioning in Children and Adults with Smith-Magenis Syndrome. Eur. J. Med. Genet. 2012, 55, 394-399. [CrossRef] [PubMed]

58. Poisson, A.; Nicolas, A.; Cochat, P.; Sanlaville, D.; Rigard, C.; De Leersnyder, H.; Franco, P.; Portes, V.D.; Edery, P.; Demily, C. Behavioral Disturbance and Treatment Strategies in Smith-Magenis Syndrome. Orphanet J. Rare Dis. 2015, 10, 111. [CrossRef]

59. Laje, G.; Morse, R.; Richter, W.; Ball, J.; Pao, M.; Smith, A.C.M. Autism Spectrum Features in Smith-Magenis Syndrome. Am. J. Med. Genet. Part C Semin. Med. Genet. 2010, 154, 456-462. [CrossRef]

60. Nag, H.E.; Nordgren, A.; Anderlid, B.-M.; Nærland, T. Reversed Gender Ratio of Autism Spectrum Disorder in Smith-Magenis Syndrome. Mol. Autism 2018, 9, 1. [CrossRef]

61. Bissell, S.; Wilde, L.; Richards, C.; Moss, J.; Oliver, C. The Behavioural Phenotype of Potocki-Lupski Syndrome: A Cross-Syndrome Comparison. J. Neurodev. Disord. 2018, 10, 2. [CrossRef]

62. Hildenbrand, H.L.; Smith, A.C.M. Analysis of the Sensory Profile in Children with Smith-Magenis Syndrome. Phys. Occup. Ther Pediatr. 2012, 32, 48-65. [CrossRef]

63. Dykens, E.M.; Smith, A.C.M. Distinctiveness and Correlates of Maladaptive Behaviour in Children and Adolescents with Smith-Magenis Syndrome. J. Intellect. Disabil. Res. 1998, 42, 481-489. [CrossRef]

64. Finucane, B.; Dirrigl, K.H.; Simon, E.W. Characterization of Self-Injurious Behaviors in Children and Adults with Smith-Magenis Syndrome. Am. J. Ment. Retard. 2001, 106, 52-58. [CrossRef]

65. Nag, H.E.; Nærland, T. Age-Related Changes in Behavioural and Emotional Problems in Smith-Magenis Syndrome Measured with the Developmental Behavior Checklist. J. Intellect. Disabil. 2020, 25, 429-440. [CrossRef] [PubMed]

66. Taylor, L.; Oliver, C. The Behavioural Phenotype of Smith-Magenis Syndrome: Evidence for a Gene-Environment Interaction J. Intellect. Disabil. Res. 2008, 52, 830-841. [CrossRef] [PubMed]

67. Finucane, B.; Haas-Givler, B. Smith-Magenis Syndrome: Genetic Basis and Clinical Implications. J. Ment. Health Res. Intellect. Disabil. 2009, 2, 134-148. [CrossRef]

68. Shayota, B.J.; Elsea, S.H. Behavior and Sleep Disturbance in Smith-Magenis Syndrome. Curr. Opin. Psychiatry 2019, 32, 73-78. [CrossRef] [PubMed]

69. Sloneem, J.; Oliver, C.; Udwin, O.; Woodcock, K.A. Prevalence, Phenomenology, Aetiology and Predictors of Challenging Behaviour in Smith-Magenis Syndrome. J. Intellect. Disabil. Res. 2011, 55, 138-151. [CrossRef] [PubMed]

70. Alaimo, J.T.; Barton, L.V.; Mullegama, S.V.; Wills, R.D.; Foster, R.H.; Elsea, S.H. Individuals with Smith-Magenis Syndrome Display Profound Neurodevelopmental Behavioral Deficiencies and Exhibit Food-Related Behaviors Equivalent to Prader-Willi Syndrome. Res. Dev. Disabil. 2015, 47, 27-38. [CrossRef] [PubMed]

71. Finucane, B.M.; Konar, D.; Givler, B.H.; Kurtt, M.B.; Scott, C.I. The Spasmodic Upper-body Squeeze: A Chalacteristic Behavior in Smith-Magenis Syndrome. Dev. Med. Child Neurol. 1994, 36, 78-83. [CrossRef]

72. Greenberg, F.; Magenis, W.; Finucane, B.M.; Smith, A.C.M.; Patel, P.I.; Lupski, J.R. Smith-Magenis Syndrome [del(17)(p11.2)] and Its Clinical Overlap with Prader-Willi Syndrome. Abstract. In Proceedings of the 45th Annual Meeting of The American Society of Human Genetics, San Francisco, CA, USA, 24-28 October 1996.

73. Smith, A.C.M.; Dykens, E.; Greenberg, F. Sleep Disturbance in Smith-Magenis Syndrome (del 17 p11.2). Am. J. Med. Genet. (Neuropsychiatr. Genet.) 1998, 81, 186-191. [CrossRef]

74. Smith, A.C.M.; Morse, R.S.; Introne, W.; Duncan, W.C. Twenty-Four-Hour Motor Activity and Body Temperature Patterns Suggest Altered Central Circadian Timekeeping in Smith-Magenis Syndrome, a Neurodevelopmental Disorder. Am. J. Med. Genet. Part A 2019, 179, 224-236. [CrossRef]

75. Agar, G.; Brown, C.; Sutherland, D.; Coulborn, S.; Oliver, C.; Richards, C. Sleep Disorders in Rare Genetic Syndromes: A Meta-Analysis of Prevalence and Profile. Mol. Autism 2021, 12, 18. [CrossRef]

76. Boudreau, E.A.; Johnson, K.P.; Jackman, A.R.; Blancato, J.; Huizing, M.; Bendavid, C.; Jones, M.P.; Chandrasekharappa, S.C.; Lewy, A.J.; Smith, A.C.M.; et al. Review of Disrupted Sleep Patterns in Smith-Magenis Syndrome and Normal Melatonin Secretion in a Patient with an Atypical Interstitial 17p11.2 Deletion. Am. J. Med. Genet. Part A 2009, 149, 1382-1391. [CrossRef] [PubMed]

77. Potocki, L.; Glaze, D.; Tan, D.X.; Park, S.S.; Kashork, C.D.; Shaffer, L.G.; Reiter, R.J.; Lupski, J.R. Circadian Rhythm Abnormalities of Melatonin in Smith-Magenis Syndrome. J. Med. Genet. 2000, 37, 428-433. [CrossRef] [PubMed]

78. Goldman, A.M.; Potocki, L.; Walz, K.; Lynch, J.K.; Glaze, D.G.; Lupski, J.R.; Noebels, J.L. Epilepsy and Chromosomal Rearrangements in Smith-Magenis Syndrome [del(17)(p11.2p11.2)]. J. Child Neurol. 2006, 21, 93-98. [CrossRef] [PubMed]

79. Boddaert, N.; De Leersnyder, H.; Bourgeois, M.; Munnich, A.; Brunelle, F.; Zilbovicius, M. Anatomical and Functional Brain Imaging Evidence of Lenticulo-Insular Anomalies in Smith Magenis Syndrome. NeuroImage 2004, 21, 1021-1025. [CrossRef]

80. Masuno, M.; Asano, J.; Arai, M.; Kuwahara, T.; Orii, T. Interstitial Deletion of 17p11.2 with Brain Abnormalities. Clin. Genet. 2008, 41, 278-280. [CrossRef]

81. Natacci, F.; Corrado, L.; Pierri, M.; Rossetti, M.; Zuccarini, C.; Riva, P.; Miozzo, M.; Larizza, L. Patient with Large 17p11.2 Deletion Presenting with Smith-Magenis Syndrome and Joubert Syndrome Phenotype. Am. J. Med. Genet. 2000, 95, 467-472. [CrossRef]

82. Capra, V.; Biancheri, R.; Morana, G.; Striano, P.; Novara, F.; Ferrero, G.B.; Boeri, L.; Celle, M.E.; Mancardi, M.M.; Zuffardi, O.; et al. Periventricular Nodular Heterotopia in Smith-Magenis Syndrome. Am. J. Med. Genet. Part A 2014, 164, 3142-3147. [CrossRef]

83. Girirajan, S.; Mendoza-Londono, R.; Vlangos, C.N.; Dupuis, L.; Nowak, N.J.; Bunyan, D.J.; Hatchwell, E.; Elsea, S.H. SmithMagenis Syndrome and Moyamoya Disease in a Patient with del(17)(p11.2p13.1). Am. J. Med. Genet. Part A 2007, 143, 999-1008. [CrossRef] 
84. Chaudhry, A.P.; Schwartz, C.; Singh, A.K. Stroke after Cardiac Surgery in a Patient with Smith-Magenis Syndrome. Tex. Heart Inst. J. 2007, 34, 247-249.

85. Vlangos, C. Refinement of the Smith-Magenis Syndrome Critical Region to $\sim 950 \mathrm{~kb}$ and Assessment of 17p11.2 Deletions. Are All Deletions Created Equally? Mol. Genet. Metab. 2003, 79, 134-141. [CrossRef]

86. Elsea, S.H.; Williams, S.R. Smith-Magenis Syndrome: Haploinsufficiency ofRAI1 Results in Altered Gene Regulation in Neurological and Metabolic Pathways. Expert Rev. Mol. Med. 2011, 13, e14. [CrossRef] [PubMed]

87. Lupski, J.R.; Stankiewicz, P. Genomic Disorders: Molecular Mechanisms for Rearrangements and Conveyed Phenotypes. PLoS Genet. 2005, 1, e49. [CrossRef] [PubMed]

88. Boot, E.; Linders, C.C.; Tromp, S.H.; van den Boogaard, M.J.; van Eeghen, A.M. Possible Underreporting of Pathogenic Variants in RAI1 Causing Smith-Magenis Syndrome. Am. J. Med. Genet. Part A 2021, 185, 3167-3169. [CrossRef] [PubMed]

89. Falco, M.; Amabile, S.; Acquaviva, F. Rai1 Gene Mutations: Mechanisms of Smith-Magenis Syndrome. Appl. Clin. Genet. 2017, 10, 85-94. [CrossRef]

90. Zori, R.T.; Lupski, J.R.; Heju, Z.; Greenberg, F.; Killian, J.M.; Gray, B.A.; Driscoll, D.J.; Patel, P.I.; Zackowski, J.L. Clinical, Cytogenetic, and Molecular Evidence for an Infant with Smith-Magenis Syndrome Born from a Mother Having a Mosaic 17p11.2p12 Deletion. Am. J. Med. Genet. 1993, 47, 504-511. [CrossRef]

91. Yang, S.P.; Bidichandani, S.I.; Figuera, L.E.; Juyal, R.C.; Saxon, P.J.; Baldini, A.; Patel, P.I. Molecular Analysis of Deletion (17)(p11.2p11.2) in a Family Segregating a 17p Paracentric Inversion: Implications for Carriers of Paracentric Inversions. Am. J. Hum. Genet. 1997, 60, 1184-1193.

92. Campbell, I.M.; Yuan, B.; Robberecht, C.; Pfundt, R.; Szafranski, P.; McEntagart, M.E.; Nagamani, S.C.S.; Erez, A.; Bartnik, M.; Wiśniowiecka-Kowalnik, B.; et al. Parental Somatic Mosaicism Is Underrecognized and Influences Recurrence Risk of Genomic Disorders. Am. J. Hum. Genet. 2014, 95, 173-182. [CrossRef]

93. Park, J.P.; Moeschler, J.B.; Davies, W.S.; Patel, P.I.; Mohandas, T.K. Smith-Magenis Syndrome Resulting from a de Novo Direct Insertion of Proximal 17q into 17p11.2. Am. J. Med. Genet. 1998, 77, 23-27. [CrossRef]

94. Goh, E.S.-Y.; Banwell, B.; Stavropoulos, D.J.; Shago, M.; Yoon, G. Mosaic Microdeletion of 17p11.2-P12 and Duplication of 17q22-Q24 in a Girl with Smith-Magenis Phenotype and Peripheral Neuropathy. Am. J. Med. Genet. A 2014, 164, 748-752. [CrossRef]

95. Acquaviva, F.; Sana, M.E.; Della Monica, M.; Pinelli, M.; Postorivo, D.; Fontana, P.; Falco, M.T.; Nardone, A.M.; Lonardo, F.; Iascone, M.; et al. First Evidence of Smith-Magenis Syndrome in Mother and Daughter Due to a Novel RAI Mutation. Am. J. Med. Genet. A 2017, 173, 231-238. [CrossRef]

96. Carmona-Mora, P.; Walz, K. Retinoic Acid Induced 1, RAI1: A Dosage Sensitive Gene Related to Neurobehavioral Alterations Including Autistic Behavior. Curr. Genom. 2010, 11, 607-617. [CrossRef] [PubMed]

97. Carmona-Mora, P.; Encina, C.A.; Canales, C.P.; Cao, L.; Molina, J.; Kairath, P.; Young, J.I.; Walz, K. Functional and Cellular Characterization of Human Retinoic Acid Induced 1 (RAI1) Mutations Associated with Smith-Magenis Syndrome. BMC Mol. Biol 2010, 11, 63. [CrossRef] [PubMed]

98. Darvekar, S.; Johnsen, S.S.; Eriksen, A.B.; Johansen, T.; Sjøttem, E. Identification of Two Independent Nucleosome-Binding Domains in the Transcriptional Co-Activator SPBP. Biochem. J. 2012, 442, 65-75. [CrossRef] [PubMed]

99. Darvekar, S.; Rekdal, C.; Johansen, T.; Sjøttem, E. A Phylogenetic Study of SPBP and RAI1: Evolutionary Conservation of Chromatin Binding Modules. PLoS ONE 2013, 8, e78907. [CrossRef] [PubMed]

100. Huang, W.-H.; Guenthner, C.J.; Xu, J.; Nguyen, T.; Schwarz, L.A.; Wilkinson, A.W.; Gozani, O.; Chang, H.Y.; Shamloo, M.; Luo, L. Molecular and Neural Functions of Rai1, the Causal Gene for Smith-Magenis Syndrome. Neuron 2016, 92, 392-406. [CrossRef]

101. Milne, T.A.; Briggs, S.D.; Brock, H.W.; Martin, M.E.; Gibbs, D.; Allis, C.D.; Hess, J.L. MLL Targets SET Domain Methyltransferase Activity to Hox Gene Promoters. Mol. Cell 2002, 10, 1107-1117. [CrossRef]

102. Nakamura, T.; Mori, T.; Tada, S.; Krajewski, W.; Rozovskaia, T.; Wassell, R.; Dubois, G.; Mazo, A.; Croce, C.M.; Canaani, E. ALL-1 Is a Histone Methyltransferase That Assembles a Supercomplex of Proteins Involved in Transcriptional Regulation. Mol. Cell 2002, 10, 1119-1128. [CrossRef]

103. Bi, W.; Saifi, G.M.; Shaw, C.J.; Walz, K.; Fonseca, P.; Wilson, M.; Potocki, L.; Lupski, J.R. Mutations of RAI1, a PHD-Containing Protein, in Nondeletion Patients with Smith-Magenis Syndrome. Hum. Genet. 2004, 115, 515-524. [CrossRef]

104. Garay, P.M.; Chen, A.; Tsukahara, T.; Rodríguez Díaz, J.C.; Kohen, R.; Althaus, J.C.; Wallner, M.A.; Giger, R.J.; Jones, K.S.; Sutton, M.A.; et al. RAI1 Regulates Activity-Dependent Nascent Transcription and Synaptic Scaling. Cell Rep. 2020, 32, 108002. [CrossRef]

105. Williams, S.R.; Zies, D.; Mullegama, S.V.; Grotewiel, M.S.; Elsea, S.H. Smith-Magenis Syndrome Results in Disruption of CLOCK Gene Transcription and Reveals an Integral Role for RAI1 in the Maintenance of Circadian Rhythmicity. Am. J. Hum. Genet. 2012, 90, 941-949. [CrossRef]

106. Garay, P.M.; Wallner, M.A.; Iwase, S. Yin-Yang Actions of Histone Methylation Regulatory Complexes in the Brain. Epigenomics 2016, 8, 1689-1708. [CrossRef] [PubMed]

107. Eberl, H.C.; Spruijt, C.G.; Kelstrup, C.D.; Vermeulen, M.; Mann, M. A Map of General and Specialized Chromatin Readers in Mouse Tissues Generated by Label-Free Interaction Proteomics. Mol. Cell 2013, 49, 368-378. [CrossRef] [PubMed]

108. Jones, W.D.; Dafou, D.; McEntagart, M.; Woollard, W.J.; Elmslie, F.V.; Holder-Espinasse, M.; Irving, M.; Saggar, A.K.; Smithson, S.; Trembath, R.C.; et al. De Novo Mutations in MLL Cause Wiedemann-Steiner Syndrome. Am. J. Hum. Genet. 2012, 91, 358-364. [CrossRef] 
109. Babbs, C.; Lloyd, D.; Pagnamenta, A.T.; Twigg, S.R.F.; Green, J.; McGowan, S.J.; Mirza, G.; Naples, R.; Sharma, V.P.; Volpi, E.V.; et al. De Novo and Rare Inherited Mutations Implicate the Transcriptional Coregulator TCF20/SPBP in Autism Spectrum Disorder. J. Med. Genet. 2014, 51, 737-747. [CrossRef]

110. Williams, S.R.; Aldred, M.A.; Der Kaloustian, V.M.; Halal, F.; Gowans, G.; McLeod, D.R.; Zondag, S.; Toriello, H.V.; Magenis, R.E.; Elsea, S.H. Haploinsufficiency of HDAC4 Causes Brachydactyly Mental Retardation Syndrome, with Brachydactyly Type E, Developmental Delays, and Behavioral Problems. Am. J. Hum. Genet. 2010, 87, 219-228. [CrossRef] [PubMed]

111. Williams, S.R.; Mullegama, S.V.; Rosenfeld, J.A.; Dagli, A.I.; Hatchwell, E.; Allen, W.P.; Williams, C.A.; Elsea, S.H. Haploinsufficiency of MBD5 Associated with a Syndrome Involving Microcephaly, Intellectual Disabilities, Severe Speech Impairment, and Seizures. Eur. J. Hum. Genet. 2010, 18, 436-441. [CrossRef] [PubMed]

112. Talkowski, M.E.; Mullegama, S.V.; Rosenfeld, J.A.; van Bon, B.W.M.; Shen, Y.; Repnikova, E.A.; Gastier-Foster, J.; Thrush, D.L.; Kathiresan, S.; Ruderfer, D.M.; et al. Assessment of 2q23.1 Microdeletion Syndrome Implicates MBD5 as a Single Causal Locus of Intellectual Disability, Epilepsy, and Autism Spectrum Disorder. Am. J. Hum. Genet. 2011, 89, 551-563. [CrossRef]

113. Mullegama, S.V.; Alaimo, J.T.; Chen, L.; Elsea, S.H. Phenotypic and Molecular Convergence of 2q23.1 Deletion Syndrome with Other Neurodevelopmental Syndromes Associated with Autism Spectrum Disorder. Int. J. Mol. Sci. 2015, 16, 7627-7643. [CrossRef]

114. Mullegama, S.V.; Pugliesi, L.; Burns, B.; Shah, Z.; Tahir, R.; Gu, Y.; Nelson, D.L.; Elsea, S.H. MBD5 Haploinsufficiency Is Associated with Sleep Disturbance and Disrupts Circadian Pathways Common to Smith-Magenis and Fragile X Syndromes. Eur. J. Hum. Genet. 2015, 23, 781-789. [CrossRef]

115. Kleefstra, T.; Kramer, J.M.; Neveling, K.; Willemsen, M.H.; Koemans, T.S.; Vissers, L.E.L.M.; Wissink-Lindhout, W.; Fenckova, M.; van den Akker, W.M.R.; Kasri, N.N.; et al. Disruption of an EHMT1-Associated Chromatin-Modification Module Causes Intellectual Disability. Am. J. Hum. Genet. 2012, 91, 73-82. [CrossRef]

116. Koemans, T.S.; Kleefstra, T.; Chubak, M.C.; Stone, M.H.; Reijnders, M.R.F.; de Munnik, S.; Willemsen, M.H.; Fenckova, M.; Stumpel, C.T.R.M.; Bok, L.A.; et al. Functional Convergence of Histone Methyltransferases EHMT1 and KMT2C Involved in Intellectual Disability and Autism Spectrum Disorder. PLoS Genet. 2017, 13, e1006864. [CrossRef] [PubMed]

117. Kleefstra, T.; Brunner, H.G.; Amiel, J.; Oudakker, A.R.; Nillesen, W.M.; Magee, A.; Geneviève, D.; Cormier-Daire, V.; van Esch, H.; Fryns, J.-P.; et al. Loss-of-Function Mutations in Euchromatin Histone Methyl Transferase 1 (EHMT1) Cause the 9q34 Subtelomeric Deletion Syndrome. Am. J. Hum. Genet. 2006, 79, 370-377. [CrossRef] [PubMed]

118. Benevento, M.; Iacono, G.; Selten, M.; Ba, W.; Oudakker, A.; Frega, M.; Keller, J.; Mancini, R.; Lewerissa, E.; Kleefstra, T.; et al. Histone Methylation by the Kleefstra Syndrome Protein EHMT1 Mediates Homeostatic Synaptic Scaling. Neuron 2016, 91, 341-355. [CrossRef] [PubMed]

119. Iacono, G.; Dubos, A.; Méziane, H.; Benevento, M.; Habibi, E.; Mandoli, A.; Riet, F.; Selloum, M.; Feil, R.; Zhou, H.; et al. Increased H3K9 Methylation and Impaired Expression of Protocadherins Are Associated with the Cognitive Dysfunctions of the Kleefstra Syndrome. Nucleic Acids Res. 2018, 46, 4950-4965. [CrossRef]

120. Loviglio, M.N.; Beck, C.R.; White, J.J.; Leleu, M.; Harel, T.; Guex, N.; Niknejad, A.; Bi, W.; Chen, E.S.; Crespo, I.; et al. Identification of a RAI1-Associated Disease Network through Integration of Exome Sequencing, Transcriptomics, and 3D Genomics. Genome Med. 2016, 8, 105. [CrossRef]

121. Berger, S.I.; Ciccone, C.; Simon, K.L.; Malicdan, M.C.; Vilboux, T.; Billington, C.; Fischer, R.; Introne, W.J.; Gropman, A.; Blancato, J.K.; et al. Exome Analysis of Smith-Magenis-like Syndrome Cohort Identifies de novo Likely Pathogenic Variants. Hum. Genet. 2017, 136, 409-420. [CrossRef]

122. Vetrini, F.; McKee, S.; Rosenfeld, J.A.; Suri, M.; Lewis, A.M.; Nugent, K.M.; Roeder, E.; Littlejohn, R.O.; Holder, S.; Zhu, W.; et al. De Novo and Inherited TCF20 Pathogenic Variants Are Associated with Intellectual Disability, Dysmorphic Features, Hypotonia, and Neurological Impairments with Similarities to Smith-Magenis Syndrome. Genome Med. 2019, 11, 12. [CrossRef]

123. Kerkhof, J.; Squeo, G.M.; McConkey, H.; Levy, M.A.; Piemontese, M.R.; Castori, M.; Accadia, M.; Biamino, E.; Della Monica, M.; Di Giacomo, M.C.; et al. DNA Methylation Episignature Testing Improves Molecular Diagnosis of Mendelian Chromatinopathies. Genet. Med. 2022, 24, 51-60. [CrossRef]

124. Aref-Eshghi, E.; Kerkhof, J.; Pedro, V.P.; Barat-Houari, M.; Ruiz-Pallares, N.; Andrau, J.-C.; Lacombe, D.; Van-Gils, J.; Fergelot, P.; Dubourg, C.; et al. Evaluation of DNA Methylation Episignatures for Diagnosis and Phenotype Correlations in 42 Mendelian Neurodevelopmental Disorders. Am. J. Hum. Genet. 2020, 106, 356-370. [CrossRef]

125. Laje, G.; Bernert, R.; Morse, R.; Pao, M.; Smith, A.C.M. Pharmacological Treatment of Disruptive Behavior in Smith-Magenis Syndrome. Am. J. Med. Genet. Part C Semin. Med. Genet. 2010, 154, 463-468. [CrossRef]

126. Müller, A.R.; Zinkstok, J.R.; Rommelse, N.N.J.; van de Ven, P.M.; Roes, K.C.B.; Wijburg, F.A.; de Rooij-Askes, E.; Linders, C.; Boot, E.; van Eeghen, A.M. Methylphenidate for Attention-Deficit/Hyperactivity Disorder in Patients with Smith-Magenis Syndrome: Protocol for a Series of N-of-1 Trials. Orphanet J. Rare Dis. 2021, 16, 380. [CrossRef] [PubMed]

127. Hagerman, R.J. Psychopharmacological Interventions in Fragile X Syndrome, Fetal Alcohol Syndrome, Prader-Willi Syndrome, Angelman Syndrome, Smith-Magenis Syndrome, and Velocardiofacial Syndrome. Ment. Retard. Dev. Disabil. Res. Rev. 1999, 5, 305-313. [CrossRef]

128. Niederhofer, H. Efficacy of Risperidone Treatment in Smith-Magenis Syndrome (del 17 pll. 2). Psychiatr. Danub. 2007, 19, 189-192. [PubMed] 
129. Kaplan, K.A.; Elsea, S.H.; Potocki, L. Management of Sleep Disturbances Associated with Smith-Magenis Syndrome. CNS Drugs 2020, 34, 723-730. [CrossRef] [PubMed]

130. Williams Buckley, A.; Hirtz, D.; Oskoui, M.; Armstrong, M.J.; Batra, A.; Bridgemohan, C.; Coury, D.; Dawson, G.; Donley, D.; Findling, R.L.; et al. Practice Guideline: Treatment for Insomnia and Disrupted Sleep Behavior in Children and Adolescents with Autism Spectrum Disorder. Neurology 2020, 94, 392-404. [CrossRef] [PubMed]

131. De Leersnyder, H.; Bresson, J.L.; de Blois, M.-C.; Souberbielle, J.-C.; Mogenet, A.; Delhotal-Landes, B.; Salefranque, F.; Munnich, A. Beta 1-Adrenergic Antagonists and Melatonin Reset the Clock and Restore Sleep in a Circadian Disorder, Smith-Magenis Syndrome. J. Med. Genet. 2003, 40, 74-78. [CrossRef]

132. Polymeropoulos, C.M.; Brooks, J.; Czeisler, E.L.; Fisher, M.A.; Gibson, M.M.; Kite, K.; Smieszek, S.P.; Xiao, C.; Elsea, S.H.; Birznieks, G.; et al. Tasimelteon Safely and Effectively Improves Sleep in Smith-Magenis Syndrome: A Double-Blind Randomized Trial Followed by an Open-Label Extension. Genet. Med. 2021, 23, 2426-2432. [CrossRef]

133. Richardson, G.S.; Zee, P.C.; Wang-Weigand, S.; Rodriguez, L.; Peng, X. Circadian Phase-Shifting Effects of Repeated Ramelteon Administration in Healthy Adults. J. Clin. Sleep Med. 2008, 4, 456-461. [CrossRef] 